\title{
Museu Paulista e trocas intelectuais na escrita da História de Afonso de Taunay
}

\author{
Karina Anhezini \\ Bolsista CAPES do Programa de pós-graduação em \\ História da UNESP, campus de Franca.
}

Durante as primeiras décadas do século XX, muitos intelectuais buscaram abarcar por meio da escrita da História a especificidade do período construindo identidades regionais/nacionais colocadas em pauta pelas mudanças que aconteciam no panorama nacional e internacional ${ }^{2}$.

Na produção historiográfica, a epopéia da conquista do Brasil pelos brasileiros ${ }^{3}$ foi escolhida como enredo privilegiado para traçar a identidade paulista. Dentre as ambiências vivenciadas pelos intelectuais dedicados à reconstrução do passado colonial, o Museu Paulista assumiu grande destaque como centro de referência da pesquisa histórica.

cargo de diretor deste Museu ocupado por Afonso de Taunay e, principalmente, as trocas intelectuais ocorridas neste local de sociabilidade comportam elementos fundamentais para a compreensão da trajetória ${ }^{4}$ deste intelectual. Nesse sentido, o objetivo deste artigo é analisar os intercâmbios estabelecidos entre Afonso de Taunay e parte de sua rede de sociabilidade vinculada às atividades do autor no Museu.

A noção de sociabilidade torna-se bastante útil quando entendida em duplo sentido: o primeiro se refere aos locais de produção e o outro privilegia as trocas ocorridas nestes locais ${ }^{5}$. A idéia de rede remete às instituições ou locais de sociabilidade que, por meio de "múltiplas e diferentes formas, alteram-se com o tempo, mas que têm como ponto nodal o fato de se constituírem nos loci de aprendizagem e trocas intelectuais" 6 . A este sentido, agrega-se a noção de microclimas espaço afetivo composto por uma variada gama de vínculos de amizades e hostilidades que permitem verificar os jogos das trocas intelectuais, os acordos e as disputas estabelecidos ${ }^{7}$.

Acredita-se que o espaço de sociabilidade representado pelo Museu Paulista tenha assumido na trajetória intelectual de Afonso de Taunay o papel de
1. Este artigo apresenta uma versão modificada do capítulo 3 da dissertação de Mestrado intitulada Intercâmbios intelectuais e a construção de uma História:Afonso D'Escragnolle Taunay 1911-1929 realizada sob orientação da Prof ${ }^{a}$. Dr ${ }^{\mathrm{a}}$. Teresa Maria Malatian, tendo obtido fomento da CAPES

2. GOMES, Ângela de Castro. Essa gente do Rio...: modernismo e nacionalismo. Rio de Janeiro:Fundação Getúlio Vargas, 1999; DE LUCA,Tânia Regina. $A$ Revista do Brasil: um diagnóstico para a (N)ação: São Paulo: Fundação Editora da UNESP, 1999 ; FERREIRA,Antônio Celso. A epopéia bandeirante: letrados, instituições, invenção histórica (18701940). São Paulo: Editora UNESP, 2002

3. TAUNAY, Afonso d'Escragnolle. Um grande bandeirante: Bartolomeu Paes de Abreu (1674- 
1738). Exploração do Paraná, do Rio Grande do Sul e de Mato Grosso; a conquista de Goiás.Anais do Museu Paulista, tomo I, p. 419, 1922

\begin{abstract}
4. A noção de trajetória empregada neste artigo foi desenvolvida principalmente no capítulo três intitulado "Por uma ciência das obras", de BOURDIEU, Pierre. Razões práticas: sobre a teoria da ação. Campinas, SP: Papirus, 1996.Ver também do mesmo autor: As regras da arte: gênese $\mathrm{e}$ estrutura do campo literário. São Paulo: Companhia das Letras, 1996. Apesar de ter como referência estes textos e outros do autor que tratam de temáticas relativas ao campo intelectual, esta análise se apóia em estudos que, pautados em tais referenciais, se dedicam a trajetórias intelectuais específicas situadas em recortes espacial e temporal mais adequados aos objetivos da pesquisa.
\end{abstract}

5. SIRINELLI, JeanFrançois. Os intelectuais. In: RÉMOND, René. Por uma bistória política. Rio de Janeiro:UFRJ/FGV, 1996.

6. GOMES, Ângela de Castro. Essa gente do Rio... Estudos Históricos, Rio de Janeiro,v. 6,n. 11, p. 65, 1993.

7.A definição de colégio invisível associada a esta idéia de sociabilidade possibilita um melhor entendimento das especificidades do espaço social verificado na análise da correspondência. De acordo com Raquel Glezer, "o colégio consiste em um grupo de pes- possibilidade para a escrita da História de São Paulo realizada pelo autor, pois facilitou a aquisição de livros e documentos, bem como fortaleceu conexões importantes para a concretização de suas obras.

A partir do início da produção a respeito de São Paulo quinhentista, seiscentista e setecentista o autor desenvolveu a escrita da História geral das bandeiras paulistas consolidando sua trajetória. Foram privilegiadas, na análise, as obras mais relevantes para os intelectuais denominados pares com o intuito de apresentar os vínculos estabelecidos e as trocas ocorridas na construção da História do Brasil realizada por Afonso de Taunay ${ }^{8}$.

\section{Museu Paulista e a possibilidade` de uma História}

\begin{abstract}
A título de novidade informo a v. que os concorrentes ao cargo são o Barros Barreto (cuja nomeação o governo pode tornar efetiva, visto ter sido membro da comissão de inquérito dos atos e administração lhering — segundo informou-me o Armando Prado) e imagina quem? O Evaristo da Veiga [...] Escrevo estas linhas ao lado do Edmur. Resultado de sua conversa com o Olavo [Egydio]: este declarou ao Edmur haver conversado com - Oscar Rodrigues Alves, secretário [dos negócios do interior], havendo o mesmo acolhido a idéia com simpatia. A coisa está neste pé. O Olavo parece que aprova francamente a idéia de tua nomeação ${ }^{10}$.
\end{abstract}

Os intercâmbios registrados nas correspondências trocadas nos primeiros meses de 1917 movimentaram-se em torno da indicação de Afonso de Taunay para o cargo de diretor do Museu Paulista. Apesar da rede de informações, mobilizada por Alípio Canteiro para quem Afonso de Taunay seria the right man in the right place ${ }^{11}$, pairava uma apreensão diante dos outros nomes apresentados para preencher a vaga. A escolha envolveu não apenas uma substituição de caráter administrativo, pois o diretor indicado assumiu a responsabilidade de preparar o Museu do lpiranga para as comemorações do Centenário da Independência o que significou transformar um museu voltado para as ciências naturais em um Museu de História.

Projetado pelo engenheiro e arquiteto italiano Tommaso Gaudêncio Bezzi inicialmente com a finalidade de representar o Monumento à Independência brasileira, o edifício em estilo neo-clássico passou a abrigar o Museu do Estado a partir de 1894. A intenção de construir um monumento foi contemporânea à declaração da Independência: D. Pedro concedeu em 1823 uma licença a pedido do barão de lguape para esse fim. Ao longo do século XIX, alguns projetos foram apresentados e, somente em 1881, a proposta feita por Bezzi foi aprovada pelo governo provincial de São Paulo após grandes divergências com intensa repercussão na imprensa ${ }^{12}$.

A primeira fase deste Museu caracterizou-se pela valorização das Ciências Naturais sob a direção do zoólogo Herman von Ihering, naturalista alemão cuja gestão exerceu entre 1894 e 1916 . Durante este período, a presença da História no museu vinculou-se principalmente ao motivo inicial de construção do palácio comemorativo da Independência e à heterogeneidade dos objetos expostos, pois as "coleções Sertório" que deram origem ao acervo do Museu Paulista foram formadas tanto de objetos científicos quanto históricos ${ }^{13}$.

A partir da década de 1910, as dificuldades em relação à escassez de recursos tornaram-se cada vez mais impeditivas. Ana Maria de Alencar Alves 
salienta o relativo desprestígio das Ciências Naturais associado aos problemas relacionados à Primeira Guerra Mundial como elementos capazes de indicar alguns motivos para os problemas enfrentados por lhering. Além disso, desentendimentos em relação à prestação de contas à Secretaria da Agricultura e à Secretaria do Interior resultaram na formação de uma Comissão Inspetora cujo objetivo foi investigar a administração de lhering. Em razão de uma direção fortemente personalista, essa comissão constatou inúmeras irregularidades. Os maiores desacordos gravitaram em torno da coleção de conchas fósseis e das conchas fluviais, do aluguel do palacete onde lhering morava, o qual desejava ver incluído como parte de seu salário, e na definição da biblioteca ${ }^{14}$. Em agosto de 1916, o naturalista foi afastado da direção e Armando Prado assumiu como diretor interino do Museu, cargo que ocupou por alguns meses.

Afonso de Taunay ocupava em 1917 uma posição de destaque no cenário intelectual, pois desde 1911 integrava o rol de sócios dos Institutos Históricos do Rio de Janeiro e de São Paulo, bem como se destacava como docente da Escola Politécnica e da Faculdade de Filosofia e Letras de São Paulo. Suas pesquisas históricas avolumavam-se com a publicação de trabalhos inéditos, edições e reedições das obras de seu pai, visconde de Taunay, e divulgação de documentos, além dos discursos produzidos para o cumprimento da função de orador do IHGSP cuja divulgação na imprensa garantia uma acentuada propaganda de suas atividades intelectuais.

As pesquisas relacionadas ao passado paulista, provavelmente aumentaram o interesse em seu nome para assumir o cargo de diretor do Museu. Após os estudos realizados para as comemorações dos centenários de Pedro Taques Paes Leme e frei Gaspar da Madre de Deus ocorridas no Instituto de São Paulo em 1914 e 1915, Afonso de Taunay continuou em busca de documentação a respeito da História colonial de São Paulo por meio dos novos intercâmbios criados nestas instituições. A entrada para a seara da História parece ter sido o argumento mais forte de sua indicação para o cargo:

\begin{abstract}
Acabo de falar com o Armando Prado que me informou: 1ㅇ haver pedido demissão do cargo de Diretor do M. Ipiranga para o qual havia sido nomeado por indicação exclusiva do Olavo Egydio. 2º que o Secretário [Oscar Rodrigues Alves] rogou-the retirasse o pedido até escolher quem o pudesse substituir, e que ele Armando aguarda esta escolha para, de fato, exonerar-se. Conversando com ele louvou e achou felicíssima a indicação do Áfonso, tanto mais quanto agora, no Museu, com a aproximação das festas do Centenário da Independência, só se pensa e se trabalha na Seção de História, particularmente na da nossa Independência. [...] Parece que tudo está simplificado: v. deve procurar o Olavo que, obtido o assentimento do Afonso e sem prejuízo deste, em matéria de vencimentos, conseguirá sem maiores dificuldades, a nomeação do Museu. (Recado do [Alípio] Canteiro) P. S. Procure falar hoje, ou amanhã, de manhã, com Olavo Egydio 15 .
\end{abstract}

A dedicação à História de São Paulo colaborou para a proposição de seu nome, mas o caráter de nomeação assumido pelo cargo sugeriu que não somente os méritos intelectuais foram levados em conta, causando então uma grande movimentação para o seu favorecimento. Anos mais tarde, Afonso de Taunay reconheceu que a apresentação de seu nome feita por Washington Luís, prefeito da cidade de São Paulo na ocasião, ao secretário do Interior Oscar Rodrigues Alves, possibilitou sua nomeação pelo presidente do Estado Altino Arantes ${ }^{16}$

Um conjunto de elementos criou condições para o historiador Afonso de Taunay assumir a direção do Museu e mudar a feição daquela instituição. Ana soas, em cada ramo do conhecimento e suas subdivisões, razoavelmente bem relacionadas entre $s i$, encontrando-se em conferências, permutando publicações e colaborando em instituições de pesquisas, além de prestígio pessoal, destino de novas idéias e orientação para abordagem de novas áreas". GLEZER, Raquel. $O f a-$ zer e o saber na obra de José Honório Rodrigues: um modelo de análise historiográfica. 1976. p. 96. Tese (Doutorado em História). Faculdade de Filosofia Letras e Ciências Humanas - Universidade de São Paulo, São Paulo.

8. LEITE, Mário. Afonso D' Escragnolle Taunay: historiador de São Paulo Capitania, Província e Estado. São Paulo: [s.n.], 1964; ELLIS, Myriam; HORCH, Érica Rosemeire. Afonso D' Escragnolle Taunay no centenário de seu nascimento. São Paulo:Secretaria da Cultura, Ciência e Tecnologia;Conselho Estadual de Artes e Ciências Humanas, 1977; MATOS, Odilon Nogueira de.Afonso Taunay bistoriador de São Paulo e do Brasil: perfil biográfico e ensaio bibliográfico. São Paulo: Museu Paulista, 1977. São obras com características muito semelhantes, apresentam na primeira parte um perfil biográfico de Afonso de Taunay que serve de indicador das principais instituições e, principalmente, relações que permearam a trajetória intelectual do autor, em seguida contribuem com o grande esforço de elencar a volumosa produção do autor e comentá-la apresentando um valioso instrumento de pesquisa. 
9. A noção de espaço de possíveis norteou a idéia de que o Museu Paulista contribuiu para a proposição de problemas e referências criando situações favoráveis para o desenvolvimento das atividades intelectuais de Afonso de Taunay. Ver: BOURDIEU, op. cit.

10. Carta deAlípio Canteiro a Afonso de Taunay, 1 de fevereiro de 1917 , APMP/FMP, $3^{\text {a }}$ entrada, pasta 295 .

11. Carta deAlípio Canteiro a Afonso de Taunay, 29 de janeiro de 1917,APMP/ FMP, $3^{\text {a }}$ entrada, pasta 295.

12.Ver: ELIAS, Maria José. Museu Paulista:memória e história. 1996. Tese (Doutorado em História) - Faculdade de Filosofia, Letras e Ciências Humanas, Universidade de São Paulo, São Paulo.

13. ALVES, Ana Maria de Alencar. O Ipiranga apropriado: ciência, política e poder. São Paulo: Humanitas/FFLCH/USP, 2001.

14. Ana Maria de Alencar Alves aponta outros motivos para os problemas enfrentados pelo cientista, principalmente sua atuação contra o desmatamento florestal.Ibid., p. 141-153. Lilia Moritz Schwarcz ressalta que pesava sobre ele acusações de que teria proferido declarações racistas feitas a respeito dos indígenas brasileiros em 1911 n'O Estado de S. Paulo. Ver: SCHWARCZ, Lilia Moritz. O espetáculo das raças: cientistas, instituições e questão racial no Brasil. São Paulo: Companhia das Letras, 1993. p. 82-83.
Cláudia Fonseca Brefe analisou a transformação do Monumento do Ipiranga em um museu histórico realizada por Afonso de Taunay entre 1917 e 1945. A autora busca apontar "como a tarefa de historiador voltado para o estudo da História do Brasil, mas sobretudo de São Paulo — ou do ponto de vista paulista — o conduz na organização e redefinição da instituição sobre novas bases"17. Para tanto, Brefe utilizou os relatórios da gestão de Afonso de Taunay, nos quais encontra-se a montagem do cenário para a comemoração do Centenário da Independência, bem como a organização de todas as salas e exposições realizadas no período. No intuito de esmiuçar os meandros do trabalho de Afonso de Taunay no Museu a autora pesquisou ainda muitas correspondências voltadas para a administração desta instituição para entender "os fundamentos, motivações, dificuldades e contradições que levaram à constituição de um dos primeiros museus históricos brasileiros" 18 .

A partir da análise da trajetória intelectual de Afonso de Taunay desde sua formação, buscando desvendar os referenciais que fundamentaram sua construção de História e os novos laços criados com a entrada nos Institutos Históricos do Rio de Janeiro e São Paulo em relação dinâmica com a produção, verificou-se que o Museu Paulista pode ser pensado como uma possibilidade de escrita da História para Afonso de Taunay. Este foi o local de produção que garantiv ao autor um grande fluxo por outras instituições, favorecendo e viabilizando a aquisição de obras e documentos, bem como conferiu a este historiador importantes consagrações no meio intelectual. Portanto, importa analisar como os vínculos e trocas ocorridos a partir deste local de produção relacionaram-se com sua escrita da História.

Afonso de Taunay estabeleceu com a entrada no Museu uma rede de intercâmbios com instituiç̃ões dedicadas ao estudo da História na Europa e América, bem como comunicou aos arquivos, institutos, academias e bibliotecas do Brasil a mudança ocorrida na direção objetivando estabelecer os vínculos necessários para a aquisição de livros, revistas, documentos e objetos para o Museu.

Os primeiros documentos que procura e adquire para as coleções do lpiranga são
mapas e cartas territoriais brasileiras e paulistas, do período colonial - entre elas
algumas absolutamente significativas para estudar os contornos originais do Brasil e de
algumas capitanias, bem como as primeiras investidas rumo aos interiores desconhecidos
do território brasileiro 19 .

Esta documentação não constituiu apenas um vasto painel de exposição do passado paulista a ser admirado nas salas do museu, mas sim foi amplamente utilizada por ele para compor seu trabalho historiográfico a respeito de São Paulo20 . Esta utilização dos documentos, bem como os comunicados realizados às instituições nacionais e internacionais ocorreram em virtude dos objetivos norteadores da atividade de Afonso de Taunay no Museu, ou seja, transformar aquela instituição num centro de pesquisa com documentação e biblioteca disponíveis para os pesquisadores.

Ao analisar os interesses que compuseram o percurso anterior do autor nos Institutos Históricos, é possível perceber a presença do passado paulista como uma de suas preocupações. A temática do bandeirismo, suscitada por Capistrano de Abreu em 1902, atrelava-se às inquietações a respeito dos costumes seiscentistas, e em 1917 já estava presente na escrita de Afonso de Taunay. Ao dirigir um museu cujo intuito do governo do Estado era transformar em histórico, essas temáticas se adensariam e tomariam força no cotidiano deste historiador. 
Os intelectuais que integravam a rede de sociabilidade de Afonso de Taunay naquele momento foram chamados a participar da obra de reformulação do espaço museal. Diante da proximidade do Centenário da Independência, a Secretaria do Interior do Estado de São Paulo solicitou a Afonso de Taunay um plano para as mudanças que deveriam ocorrer no Museu. A apresentação da proposta e os detalhes da composição das exposições, desde a obtenção de retratos, desenhos, documentação textual, até as circunstâncias de confecção dos quadros, painéis e esculturas foram detalhadamente analisadas por Ana Cláudia Fonseca Brefe. Importa, neste artigo, apenas pontuar alguns intercâmbios imprescindíveis para a compreensão da escrita da História do autor.

Tendo que escolher os personagens que deveriam figurar no hall de entrada, Afonso de Taunay mobilizou um grande número de intelectuais sócios dos institutos para decidir sobre as personagens mais adequadas e, posteriormente, contou com uma rede de buscas em diversos locais do País e exterior dos retratos, desenhos ou pinturas dos eleitos para compor a decoração.

Entre 1919 e 1921, o intercâmbio com Basílio de Magalhães, Eugênio Egas, Theodoro Sampaio, Washington Luís, Oliveira Lima e Capistrano de Abreu foi intenso, tendo como principal temática as escolhas referentes aos nomes que iriam figurar no Museu Paulista. Muitas discordâncias foram surgindo, pois cada intelectual propunha os considerados mais importantes de acordo com a área de estudo que privilegiavam. Capistrano dizia-se desinteressado pela Independência e pouco contribuiu nessa ocasião com o discípulo. Já Basílio de Magalhães e Eugênio Egas empenharam-se em propor os nomes e as disposições em que deveriam ser expostos no Museu os "vultos da Independência".

Diante das diferentes sugestões em relação aos eleitos, Afonso de Taunay argumentou que os espaços disponíveis eram muitos e a dificuldade em encontrar alguns retratos ou bustos daquelas personagens impossibilitava sua inclusão. $\bigcirc$ autor solicitou também por meio dos jornais aos familiares e demais pessoas que pudessem colaborar com indicações e doações de retratos ou qualquer material que facilitasse a confecção da decoração do Museu.

Com o intuito de ver representada a História do Brasil desde o hall de entrada até as várias salas inauguradas nos primeiros cinco anos de direção (1917-1922), Afonso de Taunay contratou pintores e escultores paulistas e cariocas. Nessas contratações, a intermediação de Eugênio Egas também merece destaque, pois, em cartas de caráter confidencial, ele declarou a Afonso de Taunay os contatos estabelecidos com artistas da Escola de Belas Artes do Rio de Janeiro na tentativa de obter quadros por valores que o Museu pudesse pagar.

\footnotetext{
No Rio estive com o pintor Fernandes Machado a quem falei sobre os retratos para o Museu. Disse-the que V. desejava-the quatro ou cinco, desde que os pintasse a preço razoável - Respondeu que pintaria - Acrescentei: - não poderemos obter do Bernardelli algum trabalho? 'Sim, respondeu o Machado, e devem também procurar o Amoedo - Se o dr. Taunay me der cinco retratos, eu me comprometo a conseguir que Amoedo e Bernardelli acompanhem os meus preços'. Isto foi no dia 24 do corrente. $\mathrm{Se} \mathrm{V}$. quiser pormenores, marque lugar para nos encontrarmos. Também estive com o bom amigo Manuel Cícero, que anda empenhado em comprar coisas de 1822 (gravuras, medalhas, livros) que ainda não existam na biblioteca. Esta cartinha é de caráter Confidencial. Seu, de coração, Egas ${ }^{21}$.
}

Após a contratação desses profissionais, começou a difícil missão de ver representado aquilo que Afonso de Taunay considerava fiel ao período,
15. Carta de Edmur aAfonso de Taunay, 24 de janeiro de 1917 , ColeçãoAfonso de Taunay, $2^{\text {a }}$ entrada, pasta 4 .

16. TAUNAY, Afonso. Comemoração do cinqüentenário da solene instituição do Museu Paulista no palácio do Ipiranga. São Paulo: Imprensa Oficial do Estado, $1946.51 \mathrm{p}$.

17. BREFE, Ana Claudia Fonseca. Um lugar de memória para a nação: o Museu Paulista reinventado por Affonso d'Escragnolle Taunay (1917-1945). 1999. p. 5. Tese (Doutorado em História) - Instituto de Filosofia e Ciências Humanas, Universidade de Campinas.

18. Ibid., p. 7.

19. Ibid., p. 80-81.

20. Ibid.

21. Carta de Eugênio Egas a Afonso de Taunay, 28 de julho de 1919,APMP/FMP, $1^{\mathrm{a}}$ entrada, pasta 110 . 
22. A respeito das relações estabelecidas entre Afonso de Taunay e os irmãos Rodolfo e Henrique Bernardelli,ver:OLIVEIRA, Gilberto Habib. O Espólio Bernardelli no Museu Paulista e o pensamento museológico de Afonso de Escragnolle Taunay: estudos teórico-metodológicos em Museologia e a historicidade do fenômeno museal. 2000. Trabalho de Conclusão de Curso (Especialização em Museologia) - Museu de Arqueologia e Etnologia,Universidade de São Paulo, São Paulo, 2000.

23. Carta de Afonso de Taunay a Henrique Bernardelli, São Paulo, 20 de julho de 1922,APMP/ FMP, $1^{\text {a }}$ entrada, pasta 117.

24. Carta de Afonso de Taunay a Henrique Bernardelli,São Paulo, 27 de setembro de 1923, APMP/ FMP, $1^{\text {a }}$ entrada, pasta 120.

25. Carta de Afonso de Taunay a Henrique Bernardelli,São Paulo, 27 de setembro de 1923, APMP/ FMP, $1^{\text {a }}$ entrada, pasta 120.

26. Ver: SEVCENKO, Nicolau. Orfeu extático na metrópole: São Paulo, sociedade e cultura nos frementes anos 20. São Paulo: Companhia das Letras, 1992.

27. ELLIS, op. cit. Esta obra, ao utilizar também correspondências, aponta relações fundamentais para a compreensão da trajetória intelectual de Afonso de Taunay, indiciando referências que deveriam ser pesquisadas, tais como as estabelecidas com: visconde deTaunay, Capistrano de Abreu, Washington Luís, Rodolfo Garcia e Max Fleiuss. adequado aos olhos dos visitantes e, principalmente, diante das expectativas de Washington Luís. A leitura das missivas trocadas entre Henrique Bernardelli ${ }^{22}$ e Afonso de Taunay permitiu depreender o clima, às vezes tenso, existente entre concepções artísticas/históricas e os interesses envolvidos na imagem do passado que seria apresentada à sociedade. Bernardelli, quando solicitado para pintar Mathias Cardoso de Almeida, "homem de face gravibunda, sobrinho de Fernão Dias Paes Leme", enviou a Taunay um esboço do quadro, o qual recebeu a seguinte avaliação:

E como este quadro vai figurar numa galeria em que todos têm atitudes heróicas, não será de recear que ele venha representando um homem numa situação despreocupada como que está a fumar? Receio que daí nasça uma certa heterogeneidade com os demais quadros e estátuas. Assim the pediria que suprimisse o cachimbo, o seu quadro deve ir ao lado da estátua do seu irmão [Rodolfo Bernardelli] que representa Pedro | [...] Ora, poderá causar estranheza ver-se um homem, figura principal da tela, a fumar entre - Imperador nesta atitude heróica e o conquistador de Goiás [...] não pensa assim? ${ }^{23}$

Esta atitude desagradou bastante o artista Henrique Bernardelli, que viu sua concepção sendo modificada, mas esta interferência não se apresentou como algo isolado referente apenas a este quadro. Para justificar essas "correções", Afonso de Taunay se pautou no entendimento pedagógico dos museus e argumentou: "Entendo que toda a razão me assiste e realmente dada a função educativa dos museus é mais natural que o quadro exalte as qualidades da resistência de nossa tropa. ${ }^{24}$ " Nesta carta, Afonso de Taunay se referiu ao quadro Retirada do Cabo de São Roque e apresentou mais um elemento para a análise: a interferência do poder estatal. A pessoa que ordenou as modificações a serem operadas no referido quadro foi o então presidente do Estado de São Paulo, Washington Luís. Afonso de Taunay serviu de intermediário nessa "negociação", e ante uma certa resistência do artista, enfatizou:

Acha ele [Washington Luís] que só seria admissível no museu uma cena combativa e não um episódio de retirada parecendo que se trata de uma debandada. Não há dúvida que o ilustre amigo não tenha o menor compromisso com o musev e é impertinência da minha parte estar a sugerir-lhe modificações. Mas eu penso que se o quadro fosse composto de acordo com o ponto de vista presidencial ser-me-ia muito fácil ajeitar a sua posição para o museu oportunamente ${ }^{25}$.

Estas cartas indicam uma importante face da composição das obras expostas no Museu realizada sob a supervisão de Afonso de Taunay: a avaliação das medidas tomadas pelo diretor. Washington Luís empenhou-se nesse período em promover a reconstrução do passado paulista por meio de várias iniciativas relacionadas ao Museu e a tantas outras instituições, bem como reformas, monumentos e um grande incentivo às atividades culturais ${ }^{26}$.

As relações estabelecidas entre Afonso de Taunay e os responsáveis pela administração pública foram se estreitando, pois cada iniciativa relativa ao Museu Paulista dependia de comunicados solicitando aprovação e verbas. Houve uma grande interferência direta dos representantes do poder público, principalmente do secretário de Negócios do Interior e de Washington Luís, nas decisões tomadas naquela instituição. Tendo se dedicado à escrita da História de São Paulo antes da vida política, Washington Luís se empenhou em proporcionar a Afonso de Taunay os meios necessários para a transformação em curso no Museu 27. 
No entanto, por meio da análise das correspondências trocadas entre eles não foi possível visualizar Afonso de Taunay como o "mentor de um projeto ideológico das autoridades e da elite paulista ${ }^{28 ", ~ c o m o ~ a f i r m a ~ A u r e l i ~ A l v e s ~ d e ~}$ Alcântara. $\bigcirc$ que se percebe ao analisar essa documentação é a intenção de representar uma imagem da História do Brasil sob a óptica paulista, ou melhor, com elementos que se quiseram privilegiar naquele momento.

Sem dúvida, a característica monumental do Museu exerceu um papel pedagógico bastante forte aos olhos do público visitante, bem como não se pode desconsiderar que a idéia de São Paulo como formador do Brasil2a estava em construção, mas imputar à atividade museológica de Taunay a idealização e prática de um projeto "executado de forma primorosa 30 " para atender aos anseios de uma elite política parece não explicar as circunstâncias de montagem do Museu, a relevância das interferências e conexões existentes e a concepção historiográfica do seu diretor.

A função pedagógica das exposições assumiu papel de destaque no desempenho das atribuições do cargo de diretor do Museu Paulista. Esta característica foi salientada principalmente quanto à montagem das representações da cidade de São Paulo por meio da iconografia:

\begin{abstract}
As "recriações" pictóricas dos ambientes da São Paulo colonial são categorizadas por Taunay como documentos iconográficos devido ao fato de terem sido "confeccionadas" com base em fontes consideradas "autênticas" pelo historiador e graças à habilidade de seus executores. É o caso das telas encomendadas segundo fotografias ou das que reproduzem literalmente desenhos de viajantes, ou ainda, da execução das esculturas dos bandeirantes Raposo Tavares e Fernão Dias Paes, dispostas no saguão central do edifício do Museu. Este procedimento não encontra paralelo na utilização dos documentos textuais: todos que integraram as exposições montadas na década de 20 eram "autênticos" e originais; nunca "recriações" textuais. Tal atitude confirma a noção de documento iconográfico associada predominantemente a uma função de reforço, não somente de um documento textual, mas também evocativa de um quadro histórico. A especificidade da iconografia, neste caso, deve-se ao fato de ela permitir a síntese de informações de naturezas diversas num formato visual. A exploração deste atributo, por Taunay, revela sua aguçada sensibilidade em relação ao poder de comunicação dos suportes iconográficos, quando mobilizados para a produção de sentido ${ }^{31}$.
\end{abstract}

A dimensão atribuída aos suportes de apresentação desta História, ou seja, os valores conferidos ao material iconográfico e textual parecem apontar para os referenciais de construção da História de Afonso de Taunay. Vinculado aos princípios da "moderna crítica histórica", o historiador expôs no Museu uma lógica de escrita da História voltada para a importância da verdade do documento, portanto as recriações pautadas em fontes autênticas como a fotografia ou os desenhos de viajantes continuavam representando uma verdade, todavia o poder de comunicação deste suporte assumiu gradações mais intensas em relação aos documentos textuais.

Esta abertura para a utilização de novas fontes foi ressaltada por muitos intelectuais dos institutos por considerarem que somente a ampliação do universo de possibilidades da documentação daria impulso à História dos costumes defendida no período. A dedicação a esta História parece ter sido afirmada nas recomposições iconográficas realizadas por Afonso de Taunay, descendente de uma família de pintores que vieram para o Brasil integrar A Missão Artística de $1816^{32}$, tema de um de seus estudos. A ênfase ao pictórico vinculada provavelmente a essas referências da ascendência e a opção por este tipo de
28. ALCÂNTARA, Aureli Alves de. Taunay e a iconografia cafeeira: discurso e recurso. 2000. p. 10.Trabalho de Conclusão de Curso (Especialização em Museologia) - Museu de Arqueologia e Etnologia,Universidade de São Paulo, São Paulo, 2000.

29. ABUD, Kátia Maria. A idéia de São Paulo como formador do Brasil. In: FERREIRA,A.C.; DE LUCA, T.;IOKOI,Z.G.Encontros com a bistória: percursos históricos e historiográficos de São Paulo.São Paulo: Editora UNESP, 1999

30. ALCÂNTARA, op. cit., p. 10.

31. LIMA, Solange Ferraz de.; CARVALHO, Vânia Carneiro de. São Paulo Antigo, uma encomenda da modernidade: as fotografias de Militão nas pinturas do Museu Paulista. Anais do Museu Paulista: História e Cultura Material, n. 1, p. 149, 1993.

32. TAUNAY, Afonso. A Missão Artística de 1816. RIHGB, v. 74, p. 3-202, 1911. Esta obra foi ampliada e revista na edição de 1956. TAUNAY, Afonso. A missão artística de 1816. Rio de Janeiro: Serviço do Patrimônio Histórico e Artístico Nacional, 1956. 
História que encontra raízes também em sua formação intelectual vinculada ao pai, visconde de Taunay, e ao mestre, Capistrano de Abreu, foi apresentada com sensibilidade nas exposições do Museu Paulista.

O papel de possibilidade desempenhado pelo Museu é afirmado aqui por considerar que somente por meio dessa posição institucional foi possível a mobilização de grande número de profissionais dedicados às reproduções de cenas históricas, de personagens cujas faces e ações puderam ser representadas nos espaços do Museu, bem como proporcionou a Afonso de Taunay dedicar-se quase exclusivamente à escrita da História.

Além da extensa rede de sociabilidade formada a partir da entrada de Afonso de Taunay no Instituto Histórico e Geográfico Brasileiro e no Instituto Histórico e Geográfico de São Paulo em 191 1, a direção do Museu possibilitou a contratação não somente de artistas para reproduzir iconograficamente o passado colonial partindo de fotografias ou desenhos, mas também de profissionais dedicados à localização e cópia de documentos de grande interesse para Afonso de Taunay. Muitas salas do Museu foram ocupadas durante a década de 1920 por essa documentação que ganhou as páginas dos Anais do Museu Paulista e das revistas dos institutos, bem como integrou em grande medida as fontes utilizadas pelo historiador em suas obras. Afonso de Taunay contou com os serviços dos experientes profissionais José Domingues e Manuel Alves de Souza, os quais forneceram informações valiosas tanto para a montagem do cenário das comemorações quanto para a confecção das obras, localizando e transcrevendo diversos documentos. A verba destinada ao Museu permitiv a Taunay pagar cópias e exemplares adquiridos por amigos intelectuais que, desde a década de 1910, auxiliaram na localização e aquisição de documentos e obras, o que facilitou 0 acesso aos arquivos e bibliotecas dos vários cantos do Brasil e da Europa.

O Museu Paulista tornou-se a partir da gestão de Taunay um centro de estudos do passado brasileiro; a transformação do museu dedicado às Ciências Naturais para um museu de História não extinguiu, contudo, de seu acervo e das publicações, os temas daquelas ciências. Portanto, a Revista do Museu Paulista, especializada principalmente em zoologia, continuou tendo seus números editados sob a responsabilidade de especialistas cuja contratação foi solicitada por Taunay meses após sua entrada em $1917^{33}$.

Seguindo este princípio de especialização do conhecimento, Taunay criou no Museu uma seção de História do Brasil e, especialmente, de São Paulo, tal como ele a definia, destinada a construir e organizar os acervos iconográficos e textuais, bem como adquirir o que ele denominou de uma brasiliana, ou seja, uma biblioteca com os principais livros e periódicos de História com o intuito de tornar a instituição uma referência obrigatória para os estudiosos interessados nos aspectos antigos da vida brasileira.

Essas iniciativas tornaram-se visíveis não somente por meio da visitação ao Museu do Ipiranga ou pela ampla divulgação na imprensa paulista, mas foram verificadas sobretudo pelos intelectuais denominados pares, e pelas autoridades nas páginas dos Anais do Museu Paulista, periódico criado por Taunay dedicado exclusivamente à publicação de estudos da área de História.

Inaugurado em 1922, o primeiro tomo integrou o rol de ações comemorativas do Centenário da Independência nacional. Dividido entre a publicação de artigos e documentos, o número inicial do periódico contou com três estudos elaborados por seu editor e com a divulgação de doze documentos 
que passaram a integrar o acervo da seção de História do Brasil do Museu Paulista. Nesse sentido, os Anais serviram nesse momento a dois propósitos: publicar os trabalhos de Taunay e as aquisições do Museu sob sua direção.

No prefácio deste tomo, Afonso de Taunay reconstituiu as ações empreendidas pelo governo do Estado de São Paulo e por ele entre 1916 e aquele ano, com o fim de salientar as mudanças efetivadas e justificá-las:

Em 1916, no Monumento do lpiranga, construído para a celebração do nosso magno acontecimento nacional de 1822, como solenemente o declara a sua grande placa inaugural, quase nada havia que lembrasse a tradição brasileira e paulista. Em dois acanhados cômodos, se espalhavam objetos heterogêneos em arrumação sobremodo defeituosa, senão absurda, quadros históricos de envolta com móveis desmantelados, objetos velhos, documentos sem valor algum histórico ou arqueológico, ali tendo ido parar ao acaso da boa vontade dos seus doadores. E por cima de tudo, todo este acervo se apresentava muito mal conservado. [...] este absoluto pouco caso pelas coisas nacionais teve conseqüências muito perniciosas. Basta lembrar que neste lapso de 23 anos, em que o Museu quase nada adquiriu para a sua seção histórica, perderamse ótimos objetos que de São Paulo foram exportados, sobretudo como mobiliário e indumentária. [...] A nomeação do Dr. Armando Prado em 1916, para a diretoria do Museu, veio reintegrar a tradição brasileira no seu verdadeiro lugar, no lpiranga. [...] Continuamos a seguir-the os passos, tanto mais quanto entendíamos que a aproximação do Centenário nos impunha a inflexibilidade desta diretriz nacionalista. Os governos dos Exmos. Srs. Drs. Altino Arantes e Washington Luís sobremodo amparam este surto. $\bigcirc$ ilustre Sr. Dr. Oscar Rodrigues Alves, Secretário de Interior do primeiro, carinhosamente auxiliou o Museu e facultou-nos, já em 1917 e 1918, os meios para abrirmos as duas primeiras salas consagradas à tradição paulista, no lpiranga. Com a aproximação das comemorações centenárias ocorreu, em 1921, a concessão de grande crédito aberto pelo atual governo, graças ao qual pôde a seção de história desenvolver-se notavelmente, apresentando a 7 de Setembro de 1922, oito salas novas, procedendo-se, contemporaneamente, à decoração do edifício, que até então estava vazio de pinturas e estátuas que a arquitetura reclamava ${ }^{34}$.

Este foi o tom empreendido por Afonso de Taunay para reconhecer o empenho dos responsáveis pela administração estadual e apontar os feitos realizados no Museu, dentre os quais a publicação dos Anais era uma conseqüência natural destes pontos de vista, ou seja, ante as iniciativas que prezaram pelo incentivo e fomento das medidas implementadas, o periódico apenas veio coroar a bem sucedida junção dos interesses do Estado em relação ao Museu e a dedicação de Taunay que buscava representar naquele espaço a História a partir de suas concepções.

Os artigos publicados por Taunay, neste primeiro tomo, foram: Pedro Taques e seu tempo (Estudo de uma personalidade e de uma época), Sob el Rey Nosso Senhor e Um grande bandeirante: Bartholomeu Paes de Abreu.

segundo tomo dos Anais foi dedicado ao estudo dos escritores coloniais. $\bigcirc$ autor justificou historiograficamente seu interesse por este tema afirmando que, ao fazer a leitura das principais obras destes autores, foi impulsionado a estudar suas biografias para compreender melhor as temáticas e abordagens tratadas nos escritos coloniais. Dessa forma, Afonso de Taunay utilizouse das obras e de documentos inéditos a respeito de alguns autores para empreender os estudos bio-bibliográficos reunidos em volume. Foram privilegiados neste estudo: padre Manuel de Morais, Pero de Moraes Madureira, Diogo Garção Tinoco, André João Antonil (João Antônio Andreoni), frei Gaspar da Madre de Deus, Manuel Cardoso de Abreu, frei Miguel Arcanjo de Annunciação, Theotônio José Juzarte e Diogo de Toledo Lara e Ordonhes. A publicação do periódico em
34. TAUNAY,Afonso. Prefácio. Anais do Museu Paulista, tomo I, p. III-IV, 1922. Comemorativo do primeiro centenário da Independência nacional. 
35. TAUNAY,Afonso. Escritores Coloniais. Subsídios para a história da literatura. Anais do Museu Paulista, tomo II, 1925.

36. Anais do Museu Paulista, tomo III, 1927.

37. TAUNAY, Afonso. Chronica do tempo dos Philippes. Tour: Imp. E. Arrault \& Cia, 1910.

38. TAUNAY, Afonso. Os princípios gerais da moderna crítica histórica. RIHGSP, v.XVI, 1914.
1925 objetivou oferecer subsídios para a história da literatura brasileira, pois se pautando no cotejo da documentação disponível com a bibliografia existente, o autor apresentou um panorama da produção destes escritores coloniais. Há nesses artigos a grande preocupação em apontar as lacunas ainda existentes pela falta de documentação, o que leva muitas vezes, segundo Taunay, a apreciações deficientes. Ao final de cada artigo, o autor arrola a bibliografia disponível, salientando que assim facilitaria o conhecimento desses autores de difícil acesso para o público em geral, dada a raridade de seus escritos ${ }^{35}$.

Após dois anos, outros estudos foram impressos nas páginas dos Anais do Museu Paulista. Afonso de Taunay dedicou o volume à publicação de estudos realizados em diversas épocas e já esparsamente divulgados em periódicos, constando desse terceiro tomo: Do Reino ao Império, Estudos de história paulista e Antigos aspectos paulistas ${ }^{36}$.

Enquanto a Revista do Museu Paulista recebeu várias contribuições divulgando diversos estudos realizados na área das Ciências Naturais, os primeiros três tomos dos Anais do Museu Paulista impressos na década de 1920 dedicaramse à publicação de artigos de Afonso de Taunay e de documentos incorporados ao acervo do Museu.

Os Anais apresentaram-se como uma publicação essencialmente paulista, quase todos os artigos tratando de temas relacionados ao passado de São Paulo. Financiado pelo governo do Estado e criado para divulgar as atividades da seção de História de um monumento à Independência proclamada em solo paulista, esse periódico nasceria com a vocação de privilegiar São Paulo em suas temáticas.

Quando Afonso de Taunay expressou a Capistrano de Abreu a vontade de se dedicar à História, este aconselhou o discípulo a abordar um tema adequado à sua posição no momento, pois se estava trabalhando na capital paulista, e se ele queria escrever História deveria estudar as bandeiras. As palavras do mestre foram desconsideradas em um primeiro momento, pois Taunay preferiu narrar por meio de um romance histórico, episódios da invasão holandesa ${ }^{37}$, mas nas fronteiras entre o romance e o método optou pelos princípios gerais da moderna crítica histórica $^{38}$, e passou então ao ofício do historiador, ingressando nos institutos históricos. Nas sessões realizadas nessas agremiações, Taunay apresentou seus primeiros estudos a respeito do tema sugerido por Capistrano. Laços anteriores se fortaleceram e novos vínculos foram estabelecidos, favorecendo a indicação de seu nome para o cargo que o tornou definitivamente reconhecido nos meios intelectuais.

Imbuído da missão de transformar o Museu do lpiranga em um museu de História voltado para o passado paulista, Afonso de Taunay teve a possibilidade de se dedicar à escrita da História quase que exclusivamente. A partir daquele momento, estudar a História de São Paulo foi condição necessária para o desempenho de suas funções no cargo de diretor do Museu Paulista e foi, portanto, por meio dessa História que ele se consagrou como o Historiador das Bandeiras.

São Paulo e a consolidação de uma trajetória intelectual

Meu querido primo e amigo,

Tenho duas cartas do primo acerca de Moreira Teles. Muito agradeço a sua intervenção valiosíssima junto de Fleiuss para que ele seja aceito no Instituto Brasileiro. [...] Felicito- 
- pelo estudo do ambiente paulista colonial no século 18. O seu trabalho preencherá uma das deficiências da nossa literatura histórica. Presumo que o primo terá que lutar com sérias dificuldades pela escassez de documentos. Se tiver necessidade de mim para alguma pesquisa não faça cerimônia. Só desejo ser mais feliz que da outra vez. [...] Como é esquiva a verdade! 39

Os primeiros trabalhos a respeito do passado colonial paulista entraram em cena na trajetória intelectual de Afonso de Taunay entre 1914 e 1915, ocasião em que apresentou os estudos a respeito de Pedro Taques e frei Gaspar da Madre de Deus. A partir destes trabalhos, o autor iniciou a análise do ambiente paulista do século XVIII, razão pela qual foi parabenizado por seu primo Manuel Gomes de Carvalho na carta acima citada, motivada pelo agradecimento diante da intervenção de Taunay junto a Max Fleiuss para a entrada de Moreira Teles no $\| \mathrm{HGB}$.

Tendo ingressado em 1911 nos Institutos Históricos do Rio de Janeiro e de São Paulo, sua influência em relação às escolhas de novos sócios já se fazia sentir nos idos de 1916, data em que a carta do primo fora produzida. Essa receptividade das opiniões de Afonso de Taunay favoreceu a produção dos primeiros estudos referentes a São Paulo, pois permearam as comemorações dos autores setecentistas diversas controvérsias que resultaram na apresentação da versão biográfica construída por Taunay.

A esquiva verdade 40 sobre Pedro Taques foi buscada na análise de Afonso de Taunay por meio do estudo de uma época ${ }^{41}$. Esta era a intenção do autor, realizar o estudo de uma personalidade em seu momento histórico. Com acuidade o autor buscou desvendar as possíveis situações vividas pelo historiador dos setecentos descrevendo sua formação, seus mestres e discípulos, as dificuldades encontradas em Goiás, a viagem para Portugal e o terremoto de Lisboa, a vida familiar do linhagista e a morte ocorrida na miséria.

Todos estes aspectos foram entrelaçados pela narrativa a respeito da descoberta de Goiás, da caracterização de São Paulo em 1765, do Morgado de Matheus, da pobreza, do primeiro recenseamento da cidade, dos escravos e dos livres, dos homens e das mulheres, das principais ruas, das igrejas, dos projetos de Bartholomeu Paes de Abreu — pai de Pedro Taques — além de muitos outros traços encontrados nos documentos pesquisados pelo autor. Afonso de Taunay preocupouse em apontar as fontes utilizadas e, principalmente, apresentar as discussões da historiografia contemporânea concernente a temas acentuadamente polêmicos.

Na análise da correspondência, é possível perceber que este estudo foi, nos primeiros anos de produção do autor, um dos mais elogiados e solicitados, pois a versão apresentada no $\|$ GGSP foi publicada em 1915 e depois aprofundada para os Anais do Museu Paulista em 1922 e ainda, serviu de prefácio à reedição da Nobiliarquia Paulistana ${ }^{42}$ sob a orientação e incentivo de Capistrano.

Não haverá alguns capítulos inéditos da Nobiliarquia a publicar agora? Isto é que seria excelente dando o maior realce ao trabalho. O seu estudo prefácio desenvolvendo a conferência do Centenário; disse-me você que será extenso à vista da documentação nova. Parabéns pelo que me conta. Sobretudo se é tão extensa e tão cheia de novidades sobre a biografia do genealogista. A descoberta do testamento representou um belo achado, como já the disse mais de uma vez. Parabéns! Vamos! [...] Taques merece um estudo aprofundado ${ }^{43}$

Iniciar a produção relativa à História de São Paulo estudando Taques e frei Gaspar parece significar a apresentação do caminho que traçou nos seus
39. Carta de Manuel Gomes de Carvalho a Afonso de Taunay, 10 de setembro de 1916, APMP/FMP, $3^{a}$ entrada, pasta 295.

40. Carta de Manuel Gomes de Carvalho a Afonso de Taunay, 10 de setembro de 1916, APMP/FMP, $3^{\text {a }}$ entrada, pasta 295.

41. TAUnaY, Afonso. Pedro Taques e seu tempo (Estudo de uma personalidade e de uma época). Anais do Museu Paulista, São Paulo, tomo I, 1922.

42. TAQUES, Pedro. Nobiliarquia paulistana, bistórica e genealógica. São Paulo: Martins/Comissão do IV Centenário da cidade de São Paulo, 1953.3 v

43. Carta de Capistrano de Abreu a Afonso de Taunay, Rio de Janeiro, idos de março de 1917, In: RODRIGUES, José Honório. Correspondência de Capistrano de Abreu. Rio de Janeiro:Civilização Brasileira; Brasília: INL, v. 3, p. 280-281, 1956 
44. ABUD, Kátia Maria. $O$ sangue intimorato e as nobilíssimas tradições (a construção de um símbolo paulista:o bandeirante). 1985. p. 21. Tese (Doutorado em História) - Faculdade de Filosofia Letras e Ciências Humanas, Universidade de São Paulo, São Paulo.

45. TAUNAY, Afonso. $\mathrm{Na}$ era das bandeiras paulistas (Aspectos de história colonial paulista). RIHGB, tomo 84, 1919. Em 1922 esta obra foi editada em livro: TAUNAY, Afonso. Na era das bandeiras. $2^{\mathrm{a}}$ ed. São Paulo: Companhia Melhoramentos de São Paulo Weiszflog Irmãos, 1922.

46. Carta de Basílio de Magalhães a Afonso de Taunay, Rio de Janeiro, 22 de junho de 1919,APMP/ FMP, $1^{\text {a }}$ entrada, pasta 109.

47. Carta de Basílio de Magalhães a Afonso de Taunay, São João del Rey, 12 de julho de 1920, APMP/FMP, $3^{\text {a }}$ entrada, pasta 295.

48. MACHADO NETO,Antônio Luís. Estrutura social da república das letras: sociologia da vida intelectual brasileira, 1870-1930. São Paulo: Grijaldo, EDUSP, 1973.

49. TAUNAY, Afonso. $A$ Glória das monções. São Paulo: Casa Editora O Livro, 1920 .

50. Carta de Alberto Rangel aAfonso deTaunay, Paris, 15 de janeiro de 1920,APMP/FMP, $3^{\text {a }}$ entrada, pasta 295. próprios desbravamentos pela História bandeirante, pois segundo o estudo de Afonso de Taunay, confirmado pela tese de Kátia Abud ${ }^{44}$, esses autores do século XVIII foram os responsáveis pelas primeiras obras a respeito do movimento das bandeiras.

Com essas análises, Afonso de Taunay, além de apresentar aos intelectuais dos institutos o interesse pelo tema, empreendeu também os estudos necessários para as próximas investidas, pois esses autores eram mananciais importantes de informações para os estudiosos. Assim, primeiramente Afonso de Taunay buscou resolver as polêmicas existentes em torno deles e sanar as insuficiências de análise a respeito de suas vidas e obras, para posteriormente publicar Na era das bandeiras ${ }^{45}$, estudo que além de utilizar as Atas das Câmaras de Santo André e de São Paulo e a bibliografia existente, pautou-se em muitos dos relatos e interpretações de Pedro Taques e frei Gaspar.

Na era das bandeiras foi aguardado por aqueles que acompanhavam os artigos esparsos publicados nos jornais: "Quando é que sai o seu trabalho sobre S. Paulo? Estou ansioso para poder ler os seus eruditos artigos enfeixados em volume." 46

Basílio de Magalhães, na época em que escreveu a carta, da qual o excerto acima é parte, havia publicado sua obra mais conhecida Expansão Geográfica do Brasil até fins do século XVIII, que teve seu título mudado para Expansão Geográfica do Brasil Colonial após a ampliação do estudo em 1935. $\bigcirc$ interesse deste intelectual pela História da conquista do território brasileiro foi expresso nas sessões do IHGSP, onde apresentou seu trabalho a respeito do Bandeirismo Paulista em 1914, mas o incentivo às pesquisas de Afonso de Taunay vinha de longa data, tendo the sugerido o tema dos viajantes, além de tê-lo ajudado na composição do hall do Museu Paulista.

Além do vol. XI dos Anais do Museu Paulista, que mostra sua pujante atividade, recebi, e li com prazer e proveito, o seu belo discurso A Glória das Monções, nitidamente impresso. Faço votos sinceros para que uma ótima saúde possibilite ao amigo continuar nessa brilhante produtividade mental, que a esse respeito, o coloca em [...] linha entre os homens de letras do Brasil ${ }^{47}$.

$\bigcirc$ discurso a que Basílio de Magalhães se refere teve enorme repercussão dentre a rede de sociabilidade de Afonso de Taunay, no jogo das trocas de elogios ${ }^{48}$ por meio de cartas às vezes utilizadas para solicitar informações, indicações de fontes, bibliografia, ou até mesmo posições nos institutos. Foi bastante mencionado o texto A Glória das Monções ${ }^{49}$, pronunciado por Taunay em 26 de abril de 1920 na cidade de Porto Feliz, em razão da ereção do monumento que marca o ponto de partida das monções para Mato Grosso naquela localidade. $\bigcirc$ discurso transformado em livro representa uma síntese que Afonso de Taunay realizou do movimento estudado de forma mais aprofundada na História Geral das Bandeiras Paulistas.

Alberto Rangel, amigo que se correspondia com Afonso de Taunay enquanto estava na França, ao receber esses dois últimos trabalhos respondeu com seu humor característico: "Viva la gracia! Que topetada mestra no bandeiral história! V. e o Basílio, com todos os diabos! dão cabo d'esse romance de penetrar no primitivo sertão. Não deixam mais nada a palitar na epopéia."50

Ao penetrar no primitivo sertão, como salientou Rangel, Afonso de Taunay encontrou sua própria consagração intelectual. Entre 1919 e 1924, durante 
a organização do Museu Paulista para a Comemoração do Centenário da Independência do Brasil, ele publicou obras de grande repercussão no meio intelectual. Para tanto, mobilizou uma intensa troca de correspondência evidenciando um grande número de relações. "A prática epistolar de um indivíduo só existe em função de um outro, para quem se enuncia uma fala e de quem se aguarda uma resposta" ${ }^{\prime \prime 1}$, portanto, este tipo de fonte permite entrever intercâmbios fundamentais para a compreensão das escolhas de temas, fontes, bibliografias e abordagens privilegiadas pelo autor.

documento assumiu papel de destaque nas produções das primeiras décadas do século XX: a preocupação com a autenticidade, com o ineditismo e com a verdade parecia significar o elo forte das alianças em torno da rede de sociabilidade na qual Afonso de Taunay estava inserido.

Afonso de Taunay havia se comprometido com esses princípios em 1911 , na ocasião em que proferiu a conferência de abertura do curso de História Universal da Faculdade de Filosofia e Letras de São Paulo. Nesse texto 52 o autor enfatizou a responsabilidade do ofício do historiador, responsabilidade esta também sentida por outros intelectuais do período.

Acabo de tirar a última prova de um trabalho, que faço publicar na Revista do Instituto do Ceará, referente ao movimento de 17; o que tínhamos de escrito até agora vai ser modificado a bem da verdade histórica; Filgueiras será melhor apreciado graças aos documentos agora conhecidos. Pena é que os capítulos das obras de Muniz Tavares e Dias Martins consagrados ao movimento Cearense encerrem tanta inexatidão, que João Brígido primeiro veja tiranias em Sampaio e o nosso inesquecível Paulinho Nogueira pinte somente com cores velhas e vistosas os atos dos Alencares; daí vê o meu distinto amigo que bem pode acontecer que o meu trabalho desencadeie alguma procela, felizmente estou aparelhado; escrevendo sobre a revolução de 1817 no Ceará cumpri um dever, obedeci às ordens da minha consciência, sempre pronta a revoltar-se contra toda e qualquer injustiça; posso calar defeitos e erros de outrem, e tenho-o feito vezes inúmeras, isso é ato de caridade, a família humana nada ganha em saber que há mais na lista de seus membros a desonrá-la, mas não me sofre a imparcialidade de juiz, que o historiador é um juiz, que se empreste a alguém erros e crimes quando esse alguém está inocente, é o caso de Filgueiras, acusado de mandar matar pobres diabos encarregados de levar a Pernambuco papéis que havia subscrito e que tinha necessidade de fazer desaparecer, é o caso de Manuel lanácio de Sampaio, pintado como verdugo e sanguinário; e tudo porque os cronistas, fiados em Theberge e João Brígido, vão se copiando nos outros. Quanta responsabilidade a de um historiador ${ }^{53}$ !

compromisso com a escrita da História apresentou-se como um dos matizes das escolhas desses autores que produziram no início do século XX. A construção da História comportava elementos variados cujas nuanças quando consideradas pareciam apontar para um universo multifacetado de conexões e referências.

imperativo do documento esteve relacionado com esse compromisso estabelecido com a verdade, e apenas a partir da publicação de novas fontes Afonso de Taunay lançou nos primeiros anos da década de 1920 suas obras a respeito de São Paulo quinhentista. Em 1939, em seu discurso de posse como presidente honorário do IHGSP, ele rememorou partes de sua trajetória e acentuou que aquele fora um momento decisivo, pois sob o princípio metodológico de que diante da inexistência dos documentos não pode haver História, "teria sido impossível qualquer serviço sem a cooperação dos primeiros abridores de picadas em tão densa selva"54. Capistrano de Abreu havia the pedido por volta de 1917, que impulsionasse seus amigos do governo a publicarem a documentação inédita de São Paulo. Nesse período, a ligação de Taunay com os responsáveis pela
51. VENANCIO, Giselle Martins. Presentes de papel: cultura escrita e sociabilidade na correspondência de OliveiraVianna, Estudos Históricos, Rio de Janeiro, n. 28, p. 23-24, 2001.

52. TAUNAY, Afonso. Os princípios gerais da moderna crítica histórica. RIHGSP,v.XVI,p.325-344, 1914.

53. Carta de Guilherme Studart (barão de Studart) a Afonso de Taunay, 21 de julho de 1917,APMP/FMP, $1^{\text {a }}$ entrada, pasta 103

54. TAUNAY, Afonso. Discurso de posse na Presidência Honorária do Instituto. RIHGSP,v.37,p. 1011, 1939. 
55. Atas das sessões realizadas em 1917. Quinta sessão ordinária, RIHGB, tomo 82, p. 762-763, 1918.

56.VENANCIO, op. cit

57. TAUNAY, Afonso. $S$. Paulo nos primeiros annos (1554-1601): ensaio de reconstituição social.Tours:Imprenta de E. Arrault et Cie, 1920. Esta obra e S. Paulo no século $X V I$ foram reeditadas pela editora Paz e Terra em 2003 e a referência completa encontra-se na bibliografia.

58. Ibid., p. IX administração pública era bastante estreita em função da transformação em curso no Museu, talvez devido a isso, tenha solicitado a Washington Luís, ou pelo menos, indicado os documentos de maior relevância para a publicação.

A respeito dessa solicitação não foram encontradas cartas ou referências nas obras, contudo Afonso de Taunay foi o historiador que melhor aproveitou e divulgou a documentação publicada. Na quinta sessão ordinária, realizada no IHGB em 27 de agosto de 1917, foi aprovada unanimemente a seguinte proposta:

Propomos que se registre na ata da presente sessão um voto de louvor ao exmo. Sr. Dr. Washington Luís Pereira de Souza pela sua iniciativa em publicar as Atas e o Registro Geral da Câmara de São Paulo, a partir de 1562 - de que já se acham impressos 15 tomos [...] Norteado pelo amor e conhecimento profundo das tradições nacionais, está o prefeito de S. Paulo a prestar um serviço da maior valia às nossas letras históricas, trazendo a público o acervo documental de extraordinária relevância. Assim o imitem os demais chefes dos executivos municipais das velhas cidades do Brasil, são os votos do Instituto Histórico e Geográfico Brasileiro saudando com especial carinho a obra promovida por seu ilustre consócio ${ }^{55}$.

Esta proposta foi assinada por Afonso de Taunay, Max Fleiuss, Ramiz Galvão, Roquette Pinto e Basílio de Magalhães intelectuais cujo intercâmbio mostrava o interesse naquela documentação e quanto foi utilizada como fonte para os trabalhos.

Logo após a publicação desses documentos, Afonso de Taunay presenteou ${ }^{56}$ seus correspondentes com a obra S. Paulo nos primeiros annos ${ }^{57}$, em busca de pareceres, pois outros volumes estavam em fase de correção das provas na França sob os cuidados de Alberto Rangel. Como sinal de gratidão pela possibilidade de pesquisa dessa documentação garantida pelo então governador do Estado de São Paulo, Washington Luís, que deu alento ao Arquivo Público do Estado fazendo publicar as Atas e o Registro Geral da Câmara paulistana de 1562 até o século XX, após o restauro e transcrição realizados por Francisco Escobar e Manuel Alves de Souza, Afonso de Taunay the dedicou esse primeiro estudo realizado a partir dessas fontes.

Em Duas Palavras, título que Afonso de Taunay conferiu a grande parte das introduções de suas obras, o autor firmou um compromisso com o leitor de que houve na pesquisa o mais escrupuloso respeito às fontes documentais, para reconstituir os primeiros anos do arraial de onde partiriam aqueles que haviam de "arrancar ao castelhano mais da metade dessa enorme área, a do Brasil atual, e fazer recuar os meridianos alexandrino e tordesilhano, até quase o sopé dos Andes, através da selva aspérrima, povoada de perigos e mistério"58.

Foi iniciada nesse livro a epopéia dos paulistas escrita por Afonso de Taunay, após o estudo daquele considerado por ele o maior historiador das bandeiras, Pedro Taques, e de uma aproximação com o tema a partir da análise de Santo André da Borda do Campo. O autor iniciou a História de São Paulo cronologicamente narrada desde seus primeiros dias registrados nas Atas da Câmara. Atenta ao pitoresco e ao psicológico, a História dos costumes começou a ser traçada por um dos seus maiores defensores no início do século XX.

Esta obra despertou o interesse de boa parte da intelectualidade dos institutos históricos, e até o exigente mestre que muitas vezes criticara seus trabalhos, principalmente pelo estilo "inadequado" com o qual escreveu, enviou-lhe uma carta em abril de 1920 reconhecendo seus méritos, e como era de costume, fazendo correções: 
Grande parte do dia de ontem empreguei lendo seu livro sobre São Paulo quinhentista. Já estou no meio e hoje ou amanhã devo terminar $V$. proporcionou-me horas agradáveis e a mesma sensação proporcionará aos leitores. Seu método de exposição tornará popular a leitura e é bem possível que a tornem mais atrativa as perífrases, alusões, etc., [...] Depois de completar a leitura, exporei algumas dúvidas. Há uma distração curiosa em seu livro: supõe as câmaras do tempo regidas pelos Filipinos. No trabalho sobre as atas, que comecei, o primeiro artigo devia intitular-se A Câmara de S. Paulo, sobre as Ordenações Manuelinas ${ }^{59}$.

Pesquisador incansável, Afonso de Taunay publicou também os demais estudos provenientes da consulta às Atas e ao Registro Geral da Câmara de São Paulo. Em S. Paulo no século XV/bo ele traça a História da vila piratiningana dando continuidade de forma linear e cronológica ao livro anterior. Prevendo as críticas pelo critério escolhido de seguir os documentos em sua própria datação, Afonso de Taunay se justifica nas páginas introdutórias denominadas Duas Palavras: "nada geralmente mais esdrúxulo do que o critério da subordinação dos fatos históricos às efemérides seculares, interrompendo-se o estudo, a descrição de uma fase evolutiva para que se não transponha um marco, cuja particularidade única venha a ser a da contagem centenária dos anos". Porém, afirma o autor, a História de São Paulo é permeada por essa especificidade, a História quinhentista se diferencia dos acontecimentos do século XVII quando ocorreu "o desabrochar de período inteiramente novo, o da ativação das entradas produzidas pelas instigações de D. Francisco de Souza aos Paulistas"01.

Assim, Afonso de Taunay narrou em detalhes a organização administrativa da vila de S. Paulo, os cardápios dos missionários, as vestimentas, os costumes, e principalmente as discussões apresentadas nas Atas a respeito dos índios. Contudo, o capítulo que apresentou maior polêmica veio quase no final do livro, após ter "reconstituído" o primeiro século de existência de São Paulo, o autor retomou as afirmações feitas por Cândido Mendes de Almeida, desabonadoras das versões deixadas pelos dois cronistas setecentistas. Contextualizando o momento de escrita do advogado maranhense, Taunay afirmou que a intolerância em relação a Pedro Taques e frei Gaspar poderia até ser compreendida, mas os próximos capítulos foram dedicados a argumentar e provar, utilizando a documentação disponível, a veracidade expressa em suas obras.

O terceiro volume da História dos primeiros tempos de São Paulo estava no prelo em 1921. Piratininga encerra a trilogia da História paulista a partir das Atas e do Registro Geral da Câmara de S. Paulo seguindo o mesmo ritmo da narrativa, percorrendo na documentação os vestígios que possibilitavam "reconstituir" a sociedade da época, objetivo comum das obras apresentadas. Segundo Taunay, aqueles volumes poderiam ser caracterizados como um mosaico com "Os mais significativos e pitorescos elementos colhidos nos documentos oficiais"62.

Avolumaram-se dentre as missivas pesquisadas os pareceres motivados por estas publicações, a aceitação destas obras no período parece ter representado uma afirmação da área de especialidade do autor. Foram várias as solicitações de exemplares e o questionamento a respeito da continuidade dos volumes.

Alberto Rangel foi o responsável pela publicação na França dos dois primeiros livros, e em 1920 dizia-se orgulhoso por participar dos bastidores de tal feito. Foi ele que ao final da impressão de S. Paulo nos primeiros anos enviara um exemplar a Lisboa, presenteando assim João Lúcio d'Azevedo, o historiador português cujo intercâmbio com Afonso de Taunay se dera por meio de Capistrano
59. Carta de Capistrano de Abreu a Afonso de Taunay,Três Corações, 12 de abril de 1920. In: RODRIGUES, op. cit., v. 3, p. 308-309.

60. TAUNAY, Afonso. $S$. Paulo no século XVI: história da vila piratiningana. Tours: E. Arrralt \& Cie, 1921.

61. Ibid., p.VI.

62. TAUNAY, Afonso. Piratininga: aspectos sociais de S. Paulo seiscentista. São Paulo: Tipografia Ideal - Heitor L Canton, 1923. p. 6. 
63. Carta de João Lúcio D'Azevedo a Afonso de Taunay, Lisboa, 19 de novembro de 1920, APMP/ FMP, $3^{\text {a }}$ entrada, pasta 295.

64. Carta de João Lúcio D'Azevedo a Afonso de Taunay, Lisboa, 6 de agosto de 1921, APMP/FMP, $3^{\text {a }}$ entrada, pasta 295. de Abreu, com quem se correspondia há alguns anos. A impressão causada pela obra deixou Afonso de Taunay bastante agradecido, pois em carta de novembro de 1920 o historiador lisboeta comentou:

Prende a atenção como um romance, e a gente sente-se viver no seio daquele Brasil rudimentar, que assim seria em todos os novos povoadores, com os seus esforços pela vida, os interesses em conflito, aquele renovar de uma ilha de Robinson, onde se tivesse reproduzido o naufrago descobridor tenho o seu livro por fundamental para a história do Brasil, descobrindo-nos a célula primitiva de onde saiu S. Paulo grande e o Rio de Janeiro maior. Quando contei as folhas li até página 90; na sessão seguinte fui até o fim. Que mais precisaria dizer-lhe?63

Interessado pelo andamento da historiografia brasileira, solicitou a Afonso de Taunay as revistas dos Institutos do Rio de Janeiro e de São Paulo, bem como a coleção de documentos utilizados na composição do livro apreciado. Em contrapartida, João Lúcio d'Azevedo representou o vínculo mais estreito do autor com os arquivos portugueses: serviu-se da presteza do amigo para conseguir cópias de documentos que expôs no Museu Paulista, que também utilizou para suprir as lacunas de suas pesquisas particulares, distinção esta nem sempre possível de se fazer, pois parte significativa das fontes expostas foi empregada por Afonso de Taunay, se não em seus livros, ao menos como temas de artigos publicados na imprensa.

A troca de pareceres foi intensa durante a década de 1920; Afonso de Taunay escreveu agradecendo pelo envio de obras e elogiando a publicação do primeiro tomo das Cartas de Antônio Vieira e da História dos Cristãos Novos. A narrativa, às vezes criticada por Capistrano de Abreu, pareceu agradar a João Lúcio d'Azevedo, que assim expressou suas considerações a respeito de S. Paulo no século XVI: "Sinceramente felicito o autor especializado o modo porque soube amenizar a secura ordinária da pesquisa, com o brilho da linguagem e o pitoresco das narrativas"64.

apego às formas literárias talvez inspiradas no estilo empregado pelo pai, visconde de Taunay, e possivelmente somado às concepções do autor no que concerne ao tipo de História pretendida, ou seja, a história dos costumes pautada na narrativa de tudo aquilo que o documento dispõe, fez das obras de Taunay o narrar da história com tons de romance.

Nem mesmo quando contrapôs versões dos autores, expondo as polêmicas da historiografia, o autor se desvinculou do estilo romanceado; inquirindo - leitor durante a narrativa, Afonso de Taunay seguiu descrevendo os fatos e apontando suas opiniões. Este artifício de conversar com as fontes e inserir o leitor nesta conversa imprimem uma sensação de verdade possível aos argumentos; desta forma, as possibilidades de explicação dos fatos tratados aparecem esgotadas até aquele ponto do conhecimento, pois, segundo a concepção historiográfica de Afonso de Taunay, somente a descoberta de novos documentos poderia modificar a interpretação exposta.

À rede de sociabilidade de Afonso de Taunay foram ofertadas as publicações tanto dos periódicos do Museu e dos institutos quanto os seus próprios ivros. Giselle Martins Venâncio analisou a troca de correspondências e presentes de papel por meio da correspondência de Oliveira Vianna, destacando que esta prática indica a construção das redes de sociabilidade por conter nestes documentos elementos variados dos intercâmbios intelectuais. 
A correspondência pessoal de um indivíduo é, portanto um espaço definidor e definido pela sua sociabilidade. E através dela que as pessoas, mesmo distantes fisicamente, podem trocar idéias e afetos, construir projetos mútuos ou discutir planos opostos, estabelecer pactos ou polêmicas e organizar ações. Esses documentos permitem, em síntese, esboçar a rede de relações sociais de seus titulares ${ }^{65}$.

Na documentação de Afonso de Taunay, cartas e obras foram trocadas com uma rede de intelectuais bastante extensa, todavia percebe-se a existência de um núcleo de autores cuja conexão estaria vinculada, sobretudo, aos Institutos Históricos dos quais Taunay pareceu sempre aguardar uma opinião, um elogio, alguma ressalva. Estes intelectuais foram os maiores responsáveis pela divulgação dos trabalhos, isto é, cada intelectual possuía intercâmbios com outras instituições, freqüentava outras rodas e, portanto, exercera o papel de arauto da produção.

Afonso de Taunay contou internacionalmente com a divulgação e avaliação de Alberto Rangel, João Lúcio d'Azevedo e Oliveira Lima, o historiadordiplomata pernambucano empenhado em montar um acervo formado por livros, documentos e obras de arte que comporiam a Oliveira Lima Library na Catholic University of América - CUA (Washington, D.C.). Afonso de Taunay e Oliveira Lima se corresponderam durante as décadas de 1910 e 1920, e a preocupação em colecionar obras e documentos motivou grande parte dessas trocas. Quando já aposentado e morando em Londres, afirmou ao amigo: "Estou, nos momentos vagos, catalogando a biblioteca, e gdo. catalogar essa parte, the mandarei dizer o volume $q$. me falta $p^{\underline{a}}$. fazer o favor de mandar-me porq. tenho a coleção completa e estimo mto. tê-la."66

Essa paixão bibliófila ${ }^{67}$ pode explicar o entusiasmo diante do presente enviado por Afonso de Taunay, o qual compôs sua biblioteca ainda não totalmente instalada em Washington na data do recebimento de S. Paulo nos primeiros annos:

[...] recebi pelo úlł․․ vapor o exemplar do seu último trabalho, tão interessante e bem documentado, sobre os começos de S. Paulo. Queira aceitar os meus agradecimentos efusivos pelo grande prazer $q$. me proporcionou essa leitura e pelo fato de se não ter esquecido de $\mathrm{qm}$. se acha distante ${ }^{68}$.

Nas análises das correspondências, é possível perceber que a sociabilidade é composta tanto por afetividades quanto por hostilidades, todavia fica reservada aos vínculos de maior estima esta prática de presentear com os livros de sua autoria, pois esta relação prevê o retorno, os comentários de incentivo, e muitas vezes o auxílio. As disputas e agressões são temas das cartas, principalmente nos momentos de conchavos e brigas por posições institucionais. Assim, o espaço de sociabilidade destinado a estas trocas de obras é, em sua maioria, caracterizado por vínculos afetivos de ajuda mútua com o intuito de colaborar no desenvolvimento de pesquisas e para completar acervos.

Tendo se dedicado desde 1914 a desbravar a História quinhentista, seiscentista e setecentista de São Paulo com enorme recepção, como se pôde observar nos pareceres dedicados a essas obras, as fontes eram suficientes e os estudos preliminares deram respaldo para iniciar em 1924 a epopéia da conquista do Brasil pelos brasileiros, que marcou definitivamente a trajetória de Afonso de Taunay.

Iniciou-se naquele ano a publicação da tão planejada História geral das bandeiras paulistas, escrita à vista de avultada documentação inédita dos 
69. TAUNAY, Afonso d'E. História geral das Bandeiras Paulistas: escrita à vista de avultada documentação inédita dos arquivos brasileiros, espanhóis e portugueses. São Paulo:Tipografia Ideal-H. L. Canton, $1924.11 \mathrm{v}$.

70. ABREU, João Capistrano de. Capítulos de bistória colonial. Belo Horizonte: Itatiaia; São Paulo: Publifolha, 2000.

71.ABUD, op.cit., p. 174 Para uma visão aprofundada das temáticas $\mathrm{e}$ abordagens tratadas por Taunay nos onze volumes da obra ver, além da tese de Kátia Abud: OLIVEIRA JÚNIOR, Paulo Cavalcante. Afonso d'E. Taunay e a construção da memória bandeirante. 1994. Dissertação (Mestrado em História) - Instituto de Ciências Sociais, Universidade Federal do Rio de Janeiro, Rio de Janeiro, 1994; COSTA, Wilma Peres. Afonso D'Escragnolle Taunay. História geral das bandeiras paulistas.In:MOTA, Lourenço Dantas. Introdução ao Brasil: um banquete no trópico. São Paulo: Editora SENAC, 2001.

72. DE LUCA, op. cit., p. 86.

73. Discurso de posse pelo Dr.Afonso d'Escragnolle Taunay. RIHGSP, v. 17, p. 89, 1912.

74. TAUNAY, Afonso. $S$ Paulo nos primeiros annos (1554-1601): ensaio de reconstituição social.Tours: Imprenta de E. Arrault et Cie, 1920. p. VIII arquivos brasileiros, espanhóis e portugueses ${ }^{69}$. $\bigcirc$ trabalho monumental de Afonso de Taunay deu origem a onze volumes publicados entre 1924 e 1950. Os estudos impressos anteriormente assumiram o caráter de ensaio, de aproximação preliminar de obras e fontes que obtiveram avaliações dos pares eleitos por Taunay e da crítica em geral.

Entretanto, para Afonso de Taunay não bastaram as análises anteriores a respeito da História de São Paulo para se proceder à síntese; as obras tratavam da ambiência inicial do movimento das bandeiras, das interpretações de Pedro Taques e frei Gaspar, das polêmicas e divergências da historiografia, mas sobretudo apontaram ao historiador as lacunas documentais existentes. Diante de tais clarões, como ele os denominou, Afonso de Taunay moveu um grande número de pessoas para garimpar nos diversos arquivos brasileiros, espanhóis e portugueses, as fontes que lhe faltavam. Assim, por meio do auxilio de amigos e particularmente contando com as facilidades que a posição de diretor do Museu Paulista lhe proporcionava, pois parte desta documentação foi incorporada ao acervo do Museu, tornando-o um centro importante de pesquisa no País, em 1924 estavam coletadas as principais fontes que comporiam os primeiros tomos.

Durante a década de 1920 foram publicados cinco tomos da obra, dedicando-se os quatro iniciais a tratar do ciclo de caça ao índio, principiando no tomo quinto o ciclo do ouro. No prefácio do primeiro, o autor enfatizou o tom empregado nas obras anteriores e denominou as bandeiras de epopéia das selvas, na qual os bandeirantes seriam os construtores épicos do Brasil, cuja importância do estudo foi apontada por Capistrano de Abreu nos Capítulos de história coloniapo.

Obra imensa de análise e não de síntese, com exaustivo tratamento das fontes reunidas durante os vinte e sete anos de sua escrita, a História geral das bandeiras paulistas abarca muitas temáticas, discute os aspectos da formação do brasileiro em variadas facetas, mas o elemento que talvez melhor a tenha caracterizado quando comparada com as produções da época é a ênfase, destacada por Kátia Abud, que Afonso de Taunay conferiu à expansão territorial ${ }^{71}$. A geografia assume papel de destaque ao lado da história para a construção desta versão historiográfica. Segundo a análise da Revista do Brasil, realizada por Tânia de Luca:

Por mais divergentes que fossem as análises a respeito da realidade nacional, pelo menos em um ponto todos pareciam concordar: o Brasil, com suas fronteiras quase continentais, ostentava um patrimônio geográfico invejável, que o distinguia dos demais países. Não é de surpreender que nos discursos sobre a nação brasileira, o espaço tenha ocupado posição destacada. A vastidão do território, um épico sempre em cartaz, alicerçou o ufanismo em seus diferentes matizes $[\ldots]^{72}$.

A tese exposta no discurso de posse no $1 H G S P$ em 1912, ocasião na qual Taunay afirmou que "nunca S. Paulo coube dentro das suas fronteiras"73, foi enfatizada no prefácio de S. Paulo nos primeiros annos, "S. Paulo centro de irradiação da conquista do Brasil pelos brasileiros, primeiro posto avançado da civilização no interior do nosso país" ${ }^{\prime 74}$, mas somente na História geral das bandeiras paulistas foi traçada a epopéia em suas minúcias, entrada por entrada, os seus integrantes, os objetivos, por que caminhos passaram, o que encontraram, quais as conseqüências e muitos outros detalhes, sempre à vista de muita documentação somada ao intenso debate com a historiografia. 
A invenção histórica da epopéia bandeirante buscou responder à seguinte questão: o que é ser paulista? Ferreira aponta que em fins do século XIX, no Almanach Litterário de São Paulo lançado em 1876, os intelectuais quiseram resgatar a História regional, no sentido literal da palavra, isto é, "retirar do cativeiro [...] a própria história regional submetida à tirania da Corte"75 e ao caracterizar a produção do IHGSP em seus primeiros quarenta anos, conclui:

Seja nas biografias, seja nas genealogias, buscava-se a construção de trajetórias incomuns, responsáveis por grandes realizações, individuais ou clânicas, fazendo-as transcender os marcos da própria colonização, com base no recuo a um passado longínquo europeu. A nobilitação das personagens revela a ambição de fixar uma epopéia paulista, sustentada por indivíduos aos quais se atribuíam uma força superior ${ }^{76}$.

Diante de tal caracterização, Afonso de Taunay encontrou-se adequado às preocupações de seu tempo, pois a História construída por ele assumiu grande pertinência diante de sua rede de sociabilidade, vinculada sobretudo aos institutos históricos. Traço facilmente observado nos tomos da História geral das bandeiras paulistas, pois os correspondentes com os quais Afonso de Taunay trocou informações a respeito de documentação e obras durante as décadas de 1910 e 1920, compuseram o núcleo central da bibliografia utilizada por ele nessa obra, o que acentuou ainda mais a importância desses vínculos na composição de sua escrita da História.

Em meados da década de 1920, Afonso de Taunay gozou do reconhecimento intelectual almejado em suas investidas no ofício da escrita da História; havia transformado o Museu do lpiranga num centro de referência para - conhecimento do passado colonial paulista, bem como num verdadeiro monumento à Independência brasileira, e assumiu posições de destaque nos institutos que lhe abriram o caminho para a História. Além disso, era comum ser solicitado para conceder pareceres às obras de intelectuais do período, ou mesmo auxiliar indicando bibliografia e documentação para a composição de obras de divulgação dos temas de sua especialidade.

Um dos autores com quem Afonso de Taunay colaborou na correção de alguns aspectos da obra, sugerindo-lhe inclusive alterações no título, foi José de Alcântara Machado de Oliveira, advogado, professor catedrático e diretor da Faculdade de Direito de São Paulo, que fez carreira política chegando a senador federal em 1935. Este jurista que elaborou o primeiro projeto para o Código Criminal Brasileiro de 1940 ficou conhecido nos meios historiográficos pela publicação de Vida e morte do bandeirante 77 , obra que the conferiu a cadeira ocupada por seu então falecido pai, Brasílio Machado, na Academia Brasileira de Letras em 1931.

Em novembro de 1925, Taunay enviou uma carta a Alcântara Machado em resposta ao seu pedido:

Com muito prazer lerei as provas de que me fala já havendo tanto apreciado os seus artigos do jornal. Muito obrigado pelas suas palavras tão amáveis. Tomo a liberdade de The fazer uma sugestão: porque não pôr no seu título vida e morte suprimindo os artigos. Parece-me mais vigoroso sendo, aliás, sobremodo feliz ${ }^{78}$.

No entanto, somente após três anos as provas ficaram prontas e foram enviadas a Afonso de Taunay que the respondeu prontamente por meio da carta cuja transcrição é apresentada na íntegra por representar um dos tipos de troca intelectual mais recorrentes no material analisado.
75. FERREIRA, op. cit., p. 60.A respeito do símbolo bandeirante, ver ainda: QUEIROZ, Maria Isaura Pereira.Ufanismo paulista: vicissitudes de um imaginário.Revista USP, n. 3, p. 79- 87, 1992.

76. Ibid., p. 128

77. MACHADO,Alcântara. Vida e morte do bandeirante. $2^{a}$ ed. São Paulo: Empresa Gráfica da Revista dos Tribunais, 1930

78. Carta de Afonso de Taunay aAlcântara Machado, São Paulo, 11 de novembro de 1925, APMP/ FMP, $1^{\text {a }}$ entrada, pasta 125. 
79. Carta de Afonso de Taunay aAlcântara Machado, São Paulo, 2 de janeiro de 1929, APMP/FMP, $1^{\text {a }}$

80. Carta de Coelho Netto aAfonso de Taunay, Rio de Janeiro, 30 de junho de 1928,APMP/FMP, $3^{\text {a }}$ entrada, pasta 295 .

81.TAUNAY,Afonso.Insuficiência e deficiência dos grandes dicionários portugueses. Tours: E. Arrault et Cie, 1928. entrada, pasta 135 .

Exmo. llustre amigo Sr. Dr. Alcântara Machado,

Tenho a honra de lhe restituir os originais do seu "O bandeirante na intimidade" que li com o maior prazer e com a maior atenção, ou antes em grande parte reli, tendo uma segunda impressão ainda melhor do que a primeira, já sua conhecida.

Muito me honra a disposição que me fez submetendo a minha apreciação o seu trabalho e por isto com redobrada atenção percorri as suas páginas. Nada tenho a the por como reparos a não ser uma ou outra coisinha de muito pormenorizada e sem importância. Assim escrevi umas notas a lápis no verso em face dos trechos analisados. Há um pequeno engano relativo à sogra de Pedro Taques. Assim também no capítulo "A justiça" página 5, chamo a sua atenção para a correção de um erro em que também já incorri, o ouvidor em 1633 era o Dr. Miguel Cirne e não Cisne, como Manuel Alves de Souza gravou erradamente, merecendo correção de Borges de Barros, da Bahia.

Permita porém que lhe observe quanto me parece preferível o seu primeiro título "Vida e morte do bandeirante" ao que agora me parece mais simpático. Enfim é uma questão de mero gosto.

No capítulo "em face da morte" ocorre-me um reparo para o qual chamo a sua atenção. $\bigcirc$ caso da morte de Antônio Pedroso de Barros. Parece-me difícil afirmar que haja sido assassinado pelos seus índios. Pedro Taques afirma que foi pelo cunhado devido a um caso de adultério.

Reiterando os muitos parabéns, peço-the que me tenha como seu mto. admr. amº. affor9 .

Este tipo de avaliação integrou o cotidiano desses "homens de letras" do início do século XX. Outra atividade bastante comum na vida de Afonso de Taunay, após a publicação das obras a respeito de São Paulo, foi uma espécie de assessoria prestada para a composição de livros comemorativos.

O romancista e poeta Coelho Netto, fundador da cadeira no 2 da Academia Brasileira de Letras, quando convidado por seus editores Lello e Irmão do Porto, para escrever uma apresentação sobre São Paulo para compor a coleção da Enciclopédia pela imagem, recorreu a Afonso de Taunay para que o auxiliasse, pedido este que parece ter sido atendido a contento, pois meses após a primeira carta, Coelho Netto agradeceu dizendo-se interessado em escrever algo a respeito dos bandeirantes:

Com os preciosos documentos com que a sua boa amizade me tem provido mais se me afervora o desejo temerário, aliás, de escrever algumas páginas sobre os gigantes, tanto tempo esquecidos nos arquivos. [...] Posto que esteja com a mão na massa do dicionário não acho termos para agradecer-lhe tanta generosidade. Fio que o tempo me proporcionará ensejo de protestar-the, de viva voz, minha gratidão ${ }^{80}$.

O dicionário a que Coelho Netto se referiv era Insuficiência e deficiência dos grandes dicionários portugueses ${ }^{81}$, que reuniu parte dos reparos publicados por Afonso de Taunay na imprensa em oposição ao Novo Dicionário da língua Portuguesa, de Cândido de Figueiredo. Esta talvez tenha sido a polêmica mais duradoura da trajetória do autor. Mesmo se dedicando intensamente à escrita da História, ele não abandonou seu interesse pela lingüística, fator que possivelmente favoreceu sua entrada para a Academia Brasileira de Letras.

O "microcosmo literário", denominado assim por Afonso de Taunay, agitouse bastante em 1929 em razão das eleições para a Academia. Aqueles cujas posições já estavam asseguradas queriam favorecer a candidatura dos aliados, os quais neste caso não eram unanimidades, em duas frentes se dividiram e mobilizaram conchavos e ataques aos adversários. A linguagem combativa inspirou-se no clima que permeou as cartas recebidas por Afonso de Taunay nesse fim da década de 1920.

Década que havia marcado sua trajetória com bastante sucesso - um 
conseqüência das transformações reconhecidamente aprovadas pelo público em geral e principalmente pelo governo do Estado, a História das bandeiras sugerida em 1902 por Capistrano encontrava-se em seu quinto tomo, porém o pequeno mundo intelectua ${ }^{82}$ possuía ainda mais posições a almejar e conquistar.

Diante da resistência de Taunay em se candidatar, alguns acadêmicos enviaram-lhe mensagens de apoio: "Permita-the dê um conselho: inscreva-se. [...] porque você é nome que todos temem. ${ }^{83 " ~ F e r n a n d o ~ N e r y ~ t a m b e ́ m ~ i n s i s t i u ~ p a r a ~}$ que Taunay se candidatasse, remetendo-lhe cartas e recados por meio de amigos comuns. Após o escrutínio, mesmo sem a unanimidade, Afonso de Taunay foi eleito e ocupou a cadeira de Luís Murat, falecido no início de 1929.

Com a nova posição assumida no cenário intelectual, ocorreram mudanças significativas na composição de sua rede de sociabilidade, novos laços se estabeleceram enquanto alguns importantes intercâmbios da trajetória intelectual e pessoal de Taunay se romperam nesse final da década de 1920 com o falecimento de alguns correspondentes, dentre eles, Capistrano de Abreu. Iniciavase com a eleição na Academia Brasileira de Letras uma segunda fase na trajetória intelectual de Afonso de Taunay.

Entretanto, os princípios gerais da concepção historiográfica do autor pareciam apresentar-se definidos, os projetos iniciados tanto no Museu Paulista quanto na História das bandeiras foram continuados nas próximas décadas, somando-se a muitos outros e a algumas posições importantes ainda alcançadas no cenário intelectual, tais como a docência no curso de História da Civilização Brasileira na Universidade de São Paulo entre 1935 e 1937, e a eleição em 1939 para presidente honorário do IHGSP.

Associando documento e arte, esse historiador compôs sua trajetória intelectual valendo-se de múltiplos intercâmbios que, ao se entrelaçarem com seus referenciais de formação, construíram uma das versões de maior força simbólica na História do Brasil: a epopéia bandeirante.

\section{REFERÊNCIAS}

ABUD, Kátia Maria. O sangue intimorato e as nobilíssimas tradições (a construção de um símbolo paulista: o bandeirante). 1985.342 f.Tese (Doutorado em História) - Faculdade de Filosofia Letras e Ciências Humanas, Universidade de São Paulo, São Paulo, 1985.

.A idéia de São Paulo como formador do Brasil. In:FERREIRA,A. C.; DE LUCA,T.; IOKOI,Z.G. Encontros com a bistória: percursos históricos e historiográficos de São Paulo. São Paulo: Editora UNESP, 1999.

ABREU, João Capistrano de. Capítulos de história colonial. Belo Horizonte: Itatiaia; São Paulo: Publifolha, 2000.

ALCÂNTARA, Aureli Alves de. Taunay e a iconografia cafeeira: discurso e recurso. 2000. $149 \mathrm{f}$. Trabalho de Conclusão de Curso (Especialização em Museologia) - Museu de Arqueologia e Etnologia, Universidade de São Paulo, São Paulo, 2000.

ALVES,Ana Maria deAlencar. O Ipiranga apropriado:ciência, política e poder. São Paulo:Humanitas/ FFLCH/USP, 2001. 
BREFE,Ana Claudia Fonseca. Um lugar de memória para a nação: o Museu Paulista reinventado porAffonso d'Escragnolle Taunay (1917-1945). 1999.304 f.Tese (Doutorado em História) - Instituto de Filosofia e Ciências Humanas, Universidade de Campinas, Campinas, 1999.

BOURDIEU, Pierre. Razões práticas: sobre a teoria da ação. Campinas, SP: Papirus, 1996.

As regras da arte: gênese e estrutura do campo literário. São Paulo: Companhia das Letras, 1996.

COSTA, Wilma Peres.Afonso D'Escragnolle Taunay. História geral das bandeiras paulistas. In: MOTA, Lourenço Dantas. Introdução ao Brasil: um banquete no trópico. São Paulo: Editora SENAC, 2001.

DE LUCA,Tânia Regina. A Revista do Brasil: um diagnóstico para a (N)ação: São Paulo: Fundação Editora da UNESP, 1999.

ELIAS, Maria José.Museu Paulista: memória e história. 1996. 473 f.Tese (Doutorado em História) Faculdade de Filosofia, Letras e Ciências Humanas, Universidade de São Paulo, São Paulo, 1996.

ELLIS, Myriam; HORCH, Érica Rosemeire. Afonso D' Escragnolle Taunay no centenário de seu nascimento. São Paulo: Secretaria da Cultura, Ciência e Tecnologia; Conselho Estadual de Artes e Ciências Humanas, 1977.

FERREIRA,Antônio Celso. A epopéia bandeirante: letrados, instituições, invenção histórica (18701940). São Paulo: Editora UNESP, 2002.

GLEZER, Raquel. O fazer e o saber na obra de José Honório Rodrigues: um modelo de análise historiográfica. 1976. 2 v. Tese (Doutorado em História) - Faculdade de Filosofia Letras e Ciências Humanas, Universidade de São Paulo, São Paulo, 1976.

GOMES, Ângela de Castro. Essa gente do Rio... Estudos Históricos, Rio de Janeiro, v. 6, n. 11, 1993.

.Essa gente do Rio...: modernismo e nacionalismo. Rio de Janeiro: Fundação Getúlio Vargas, 1999.

LEITE, Mário.Afonso D'Escragnolle Taunay: historiador de São Paulo Capitania,Província e Estado. São Paulo: [s.n.], 1964.

LIMA, Solange Ferraz de.; CARVALHO, Vânia Carneiro de. São Paulo Antigo, uma encomenda da modernidade: as fotografias de Militão nas pinturas do Museu Paulista. Anais do Museu Paulista: História e Cultura Material, n. 1, 1993,p.147-174.

MACHADO,Alcântara. Vida e morte do bandeirante. $2^{\text {a }}$ ed. São Paulo: Empresa Gráfica da Revista dos Tribunais, 1930.

MACHADO NETO, Antônio Luís. Estrutura social da república das letras: sociologia da vida intelectual brasileira, 1870-1930. São Paulo: Grijaldo, EDUSP, 1973. 
MATOS, Odilon Nogueira de.Afonso Taunay bistoriador de São Paulo e do Brasil: perfil biográfico e ensaio bibliográfico. São Paulo: Museu Paulista, 1977.

OLIVEIRA, Gilberto Habib. O Espólio Bernardelli no Museu Paulista e o pensamento museológico de Afonso de Escragnolle Taunay: estudos teórico-metodológicos em Museologia e a historicidade do fenômeno museal. 2000.94 f.Trabalho de Conclusão de Curso (Especialização em Museologia) - Museu de Arqueologia e Etnologia, Universidade de São Paulo, São Paulo, 2000.

OLIVEIRA JÚNIOR, Paulo Cavalcante. Afonso d'E.Taunay e a construção da memória bandeirante. 1994. 204 f. Dissertação (Mestrado em História) - Instituto de Ciências Sociais, Universidade Federal do Rio de Janeiro, Rio de Janeiro, 1994.

RODRIGUES, José Honório. Correspondência de Capistrano de Abreu. Rio de Janeiro: Civilização Brasileira; Brasília: INL, 1956. v. 3.

SCHWARCZ, Lilia Moritz. O espetáculo das raças: cientistas, instituições e questão racial no Brasil. São Paulo: Companhia das Letras, 1993.

SEVCENKO, Nicolau. Orfeu extático na metrópole: São Paulo, sociedade e cultura nos frementes anos 20. São Paulo: Companhia das Letras, 1992.

SIRINELLI, Jean-François. Os intelectuais. In: RÉMOND, Réne. Por uma bistória política. Rio de Janeiro: UFRJ/FGV, 1996.

TAQUES, Pedro. Nobiliarquia Paulistana, Histórica e Genealógica. São Paulo: Martins/Comissão do IV Centenário da cidade de São Paulo, 1953.3 v.

TAUNAY,Afonso. Chronica do tempo dos Philippes. Tour: Imp. E.Arrault \& Cia, 1910.

. Comemoração do cinqüentenário da solene instituição do Museu Paulista no palácio do Ipiranga. São Paulo: Imprensa Oficial do Estado, 1946.51p.

. Discurso de posse na Presidência Honorária do Instituto. RIHGSP, v. 37, p. 5-14, 1939.

.Escritores Coloniais. Subsídios para a história da literatura, Anais do Museu Paulista, tomo II, 294 p., 1925.

A glória das monções. São Paulo: Casa Editora O Livro, 1920.

.História geral das bandeiras paulistas: escrita à vista de avultada documentação inédita dos arquivos brasileiros, espanhóis e portugueses. São Paulo:Tipografia Ideal-H. L. Canton, 1924. 11 v.

Insuficiência e deficiência dos grandes dicionários portugueses. Tours: E.Arrault et Cie,

1928.

A missão artística de 1816. Rio de Janeiro: Serviço do Patrimônio Histórico e Artístico Nacional, 1956. 
. Na era das bandeiras. $2^{\text {a }}$ ed. São Paulo: Companhia Melhoramentos de São Paulo - Weiszflog Irmãos, 1922.

Pedro Taques e seu tempo (Estudo de uma personalidade e de uma época). Anais do Museu Paulista, São Paulo, tomo I, p.417-528, 1922.

Piratininga: aspectos sociais de S. Paulo seiscentista. São Paulo:Tipografia Ideal - Heitor L Canton, 1923.

. Prefácio. Anais do Museu Paulista - Comemorativo do primeiro centenário da Independência nacional, tomo I, p. III-IV, 1922.

Os princípios gerais da moderna crítica histórica. RIHGSP, v. XVI, p. 323-344, 1914.

S. Paulo no século XVI: história da vila piratiningana.Tours: E.Arrralt \& Cie, 1921.

S. Paulo nos primeiros annos (1554-1601): ensaio de reconstituição social.Tours:Imprenta de E.Arrault et Cie, 1920.

São Paulo nos primeiros anos: ensaio de reconstituição social; São Paulo no século XVI: história da vila piratiningana. São Paulo: Paz e Terra, 2003.

.Um grande bandeirante: Bartolomeu Paes de Abreu (1674-1738). Exploração do Paraná, do Rio Grande do Sul e de Mato Grosso; a conquista de Goiás.Anais do Museu Paulista, tomo I, p.417$528,1922$.

VENANCIO, Giselle Martins. Presentes de papel:cultura escrita e sociabilidade na correspondência de Oliveira Vianna, Estudos Históricos, Rio de Janeiro, n. 28, p. 23-47, 2001.

Artigo apresentado em 8/2003. Aprovado em 9/2003. 
Museu Paulista e trocas intelectuais na escrita da História de Afonso de Taunay

Karina Anhezini

Com o objetivo de compreender a trajetória intelectual de Afonso Taunay pretende-se analisar os intercâmbios estabelecidos entre este historiador e parte de sua rede de sociabilidade reunida em torno da escrita da História de São Paulo no período de 1911 a 1929. Acredita-se que o Museu Paulista assumiu o papel de possibilidade para a escrita da História realizada pelo autor, facilitando a aquisição de obras e documentos, bem como fortalecendo conexões importantes para a concretização de suas obras. A correspondência apresenta-se como principal fonte deste estudo.

PALAVRAS-CHAVE: Intercâmbios.Trajetória intelectual. Correspondência. Museu Paulista. Historiografia. Anais do Museu Paulista. São Paulo. N. Sér.v. 10/11.p.37-60 (2002-2003).

Museu Paulista (Paulista Museum) and intelectual exchanges in the wrintings of Afonso de Taunay's history

Karina Anhezini

Aiming to understand Afonso de Taunay's intellectual trajectory one intends to analyze the exchanges established among this historian and part of his sociability net gathered around the writing of the History of São Paulo in the period from 1911 to 1929. It is believed that Museu Paulista assumed the possibility role for the writing of the History accomplished by the author, facilitating the acquisition of works and documents, as well as strengthening important connections for the materialization of its works. The correspondence comes as the main source for this study.

KEYWORDS: Interchanges. Intellectual trajectory. Correspondence. Museu Paulista. Historiography. Anais do Museu Paulista. São Paulo. N. Sér.v. 10/11.p.37-60 (2002-2003)

Arquivo Aguirra. Fonte Documental sobre a formação territorial de São Paulo

\section{Walter Pires}

artigo trata da importância do Arquivo Aguirra, acervo documental produzido, coletado e organizado por João Baptista de Campos Aguirra (1871-1962), como fonte de informações sobre a formação territorial de São Paulo. Essa coleção, adquirida pelo Museu Paulista em 1962, foi utilizada nas pesquisas que resultaram no texto Configuração territorial, urbanização e patrimônio: Colônia da Glória (1876-1904), dissertação de mestrado para a FAU-USP. A organização dos dados de algumas das séries documentais desse Arquivo, através de um banco de dados informatizado, colaborou na interpretação de tendências de alteração fundiária na área da Glória no final do século XIX, destacando-se: a identificação de proprietários e de negócios imobiliários relevantes; o estabelecimento das etapas de concentração e divisão fundiárias; a valorização dessas propriedades.

PALAVRAS-CHAVE: São Paulo. Coleções. Museu Paulista. Formação territorial urbana.

Anais do Museu Paulista. São Paulo. N. Sér. v. 10/11. p.61-78 (2002-2003).

Aguirra Archives. Documental source about the territorial formation of São Paulo

Walter Pires

The article is about the importance of the Aguirra Archives, a documental collection produced, gathered and organized by João Batista de Campos Aguirra (1871-1962), as a source of information about the territorial formation of São Paulo. This collection, acquired by Museu Paulista in 1962, was used in the researches which resulted in the text Territorial, urbanization and patrimony configuration: Glória's Colony (Colônia da Glória) (1876-1904), master-degree dissertation at FAU-USP. The organization of some of these Archives' series data, through a computerized data bank, helped in the interpretation of the tendencies of land alterations in the area of Glória in the end of the 19th century, with distinction to: the identification of landlords and of relevant estate businesses; the settlement of the concentration and land division phases; the valorisation of these properties. 